Biografistyka Pedagogiczna

Rok 1 (2016) nr 1

ISSN 2543-6112; e-ISSN 2543-7399

DOI: 10.36578/BP.2016.01.02

Helena Głogowska*

\title{
Dylematy tożsamościowe na pograniczu polsko-białoruskim
}

\section{Identity Dilemmas in the Polish-Belarusian Borderland}

\begin{abstract}
The identity of the population in the Polish-Belarusian borderland depends on a number of objective and subjective factors. National identification is often secondary to cultural and religious identity. The predominant national indifference which occurs in this area (the so-called 'locality' i.e. 'I'm local') contributes to the formation of stereotypes, or reduces national identity to religious identity: 'Poles are Catholics', 'Belarusians are Orthodox'. The Polish-Belarusian borderland itself is somehow a vague area due to the absence of clear boundaries. This complex situation is a result of various cultural, historical and political influences. The relatively late - in comparison with the Polish or Russian national awareness - evolution of the Belarusian national consciousness and the lack of tradition of a Belarusian state are of particular importance. As there are no clear natural ethnic boundaries and no national Belarusian traditions in the Polish-Belarusian borderland, the borders of national identity run across families - various national options may reveal themselves in one family: Polish, Belarusian, Lithuanian, Jewish and Russian. National identity dilemmas are affected by factors such as: the degree of national consciousness, language, attachment to tradition, knowledge of history, religious affiliation, historical experience, political situation and opportunism.
\end{abstract}

Keywords: Polish-Belarusian borderland, national identity, cultural identity, religious identity, Belarusians, borderlands

* Helena Głogowska - dr hab., prof. Wyższej Szkoły Informatyki i Ekonomii TWP w Olsztynie,lenabia@interia.pl. 
Wobec ciągle aktualnego problemu związanego z dylematami na pograniczu polsko-białoruskim można postawić hipotezę, że są one spowodowane spuścizną po Wielkim Księstwie Litewskim, w którym zaznaczyły się różne wpływy kulturowe - wschodnie i zachodnie - religijne (pogaństwo, chrześcijaństwo wschodnie, zachodnie, judaizm, islam), późnym pojawieniem się w przestrzeni kategorii nowoczesnego narodu i koniunkturalnym wykorzystywaniem jej przez władze polityczne oraz ludność. Była przestrzeń Wielkiego Księstwa Litewskiego stała się swoistym pograniczem polsko-białoruskim, na którym, po jego upadku, ścierały się różne wpływy polityczne: rosyjskie, polskie, niemieckie, litewskie, białoruskie, które aspirowały do dominacji na tym terytorium. Jaki był tego efekt w XX w., pokazują zmieniające się granice państwowe. Pojawiają się więc pytania: 1) Jakie czynniki wpływały i jakie kryteria powodowały dylematy tożsamościowe?; 2) Jak język, wyznanie, stan świadomości narodowej, koniunktura polityczna wpływały na te dylematy?

Pogranicze polsko-białoruskie jest kategorią niejednoznaczną, różnie pojmowaną. Pojęcie pogranicza zawiera w sobie wiele sensów i bywa stosowane w różnych znaczeniach. Jest nią przestrzeń ukształtowana „historycznie (w związku ze zmianami granic i układów państwowych oraz migracjami ludności)”, zamieszkała „przez ludzi znajdujących się w specyficznej sytuacji (pogranicznej - innej niż w centrum) z punktu widzenia swojej tożsamości i kultury, w tym stosunku do religii i języka lub języków, w przypadku wielojęzyczności"2. Można mówić o różnych wymiarach pogranicza: personalnym, społecznym, sytuacyjnym. Wiele socjologicznych i socjolingwistycznych definicji pogranicza określa je jako „miejsce zetknięcia się, przenikania, nakładania itp. różnych narodów czy grup etnicznych, ich kultur i języków"3.

W przypadku pogranicza polsko-białoruskiego można stwierdzić, że wyznacza je wiele czynników. Wśród nich istotne znaczenie ma historia i kształtowanie się granic politycznych, zwłaszcza po unii polsko-litewskiej w Krewie w 1385 r., a następnie po unii lubelskiej w 1569 r. Koegzystencja w Rzeczypospolitej charakteryzowała się cechami takimi, jak np. rozprzestrzenianie się elementów kultury zachodniej na ziemiach białoruskich po unii polsko-litewskiej. Różne etnosy, zamieszkujące Rzeczypospolitą, posłu-

1 E. Smułkowa, Wokót pojęcia pogranicza. Wschodnie i zachodnie pogranicze Białorusi, w: Pogranicza Białorusi w perspektywie interdyscyplinarnej, red. E. Smułkowa, A. Engelking, Warszawa 2007, s. 5.

2 Tamże.

3 Cyt. za: tamże, s. 5-6. 
gujące się różnymi językami, poddawały się różnym wpływom, m.in. religijnym, językowym czy kulturowym. Samuel Huntington na pograniczu polsko-białoruskim (przez środek obecnej Białorusi) wskazał wschodnią granicę cywilizacji zachodniej, która ustaliła się około 1500 roku4 ${ }^{4}$ Oddziaływanie chrześcijaństwa wschodniego i zachodniego na przestrzeni dziejów uczyniło z religii ważny czynnik identyfikacji na pograniczu polsko-białoruskim, poczynając od XIV w. Potem nałożyło się na to pojęcie „narodowość", co doprowadziło do częstego utożsamiania kategorii wyznaniowej z narodową. Chociaż etnosy rozmawiały własnymi językami, w sferze publicznej na pograniczu dominował język urzędowy, właściwy dla grup panujących politycznie. W praktyce wiązało się to z wpływami języka polskiego na obszar Wielkiego Księstwa Litewskiego, a następnie - po rozbiorach Rzeczypospolitej - języka rosyjskiego. Język białoruski jako język urzędowy w Wielkim Księstwie Litewskim po unii lubelskiej zaczął tracić na znaczeniu i przetrwał w użyciu potocznym - często jako "prosty” język do początku xx w. Na te wszystkie wpływy nałożyła się kwestia narodowa, która stała się dominującą na początku XX w., aby w obliczu pierwszej wojny światowej sprowokować powstanie państw narodowych.

Mówiąc o pograniczu polsko-białoruskim, trudno wyznaczyć jego obszar geograficzny. Wobec oddziaływania wielu czynników terytorium to stało się płynne i niejednoznaczne. Elżbieta Smułkowa stwierdziła, że

[...] wprawdzie etnografowie wytyczają zasięgi poszczególnych elementów dawnej kultury ludowej i językoznawcy - cech dialektycznych, a historycy wskazują kierunki ruchów osadniczych i przebieg historycznych granic politycznych i administracyjnych, co ułatwia myślenie o jakimś obszarze jako pogranicznym w sensie kulturowym, ale na tym się owa terytorialność w zasadzie kończy. Czyli nawet terytorialnie rozumiane pogranicze jest tworem myślowym, bardziej konstrukcją wyobrażeniową badacza (opartą wprawdzie na realiach) niż bytem fizycznym ${ }^{5}$.

Justyna Straczuk, badająca pogranicze prawosławno-katolickie, stwierdziła, że ma ono

[...] bardziej naturę symboliczną niż fizyczną. Nie można bowiem ustalić topograficznej granicy kulturowej ani tym bardziej międzygrupowej granicy etnicznej. Granice nie biegną między grupami, ale są zinternalizowane, przebiegają

4 S. Huntington, Zderzenie cywilizacji i nowy kształt ładu światowego, przeł. H. Jankowska, Warszawa 1997, s. 231.

5 E. Smułkowa, Wokót pojęcia pogranicza, s. 7. 
wewnątrz człowieka. Nie da się wobec tego ustalić zewnętrznych obiektywnych granic wyznaniowych, nawet mimo, wydawałoby się, jednoznacznej instytucjonalnej przynależności do Kościoła katolickiego czy prawosławnego. Miejscem kontaktu kulturowego jest bowiem zawsze jednostka, która uwikłana w różne relacje - społeczne, rodzinne, lokalne, wyznaniowe - prezentuje własny, indywidualny układ kulturowy, rozmaicie wykorzystywany i interpretowany ${ }^{6}$.

Ponieważ pogranicze polsko-białoruskie jest wieloaspektowe i trudne do zdefiniowania i określenia jego zasięgu, pojawiają się na nim problemy z identyfikacją jego mieszkańców, którzy często nie potrafią określić swojej tożsamości, wykraczającej poza „swojskość", „tutejszość" w opozycji do „obcości” czy „inności”.

„Specyficzną kwestią na pograniczu kultur jest określenie tożsamości narodowej poszczególnych jednostek" - stwierdził Andrzej Chodubski. Zauważył w tym względzie: 1) tożsamość autochtoniczną, 2) tożsamość narodu stanowiącego większość w strukturze państwowej, 3) tożsamość mniejszości narodowych w strukturze państwowej, 4) tożsamość zmierzającą do dwu- bądź więcej kierunkowości, 5) tożsamość dwukierunkowości, 6) sprzeczności w obrębie tożsamości . Zwraca uwagę na płynność kryteriów:

nie ma bowiem jednoznacznych wyróżników, które precyzyjnie określałyby tożsamość narodową; często za kryteria przyjmuje się w tym względzie: zwyczaje, obyczaje, wzory zachowań, wartości, wierzenia (a w tym religię), język, doświadczenie losów społeczno-politycznych, a nawet terytorium, z którego się wywodzi ${ }^{8}$.

Świadomość narodowa jest szczególnie trudną kategorią identyfikacyjną na pograniczu polsko-białoruskim, gdyż różne - zarówno subiektywne, jak i obiektywne - czynniki wpływały na nią. Świadomości polska i litewska kształtowały się na tym pograniczu znacznie wcześniej niż białoruska. Kim zatem czuli się mieszkańcy pogranicza polsko-białoruskiego? W literaturze można spotkać odzwierciedlenie ich dylematów tożsamościowych:

Długo zastanawiałem się i myślałem, jak siebie nazywać, czy to Polakiem, czy to Litwinem, bo słowo „tutejszy” jakoś nie smakowało. I tak przez ileś lat zwraca-

6 J. Straczuk, Cmentarz i stót. Pogranicze prawosławno-katolickie w Polsce i na Białorusi, Wrocław 2006, s. 246.

7 A. Chodubski, $O$ tożsamości na pograniczu kultur, w: Dziedzictwo przeszłości związków językowych, literackich i kulturowych polsko-wschodniosłowianskich, t. 4: Kultura i literatura, red. J. F. Nosowicz, Białystok 2000, s. 11.

8 Tamże. 
łem się to w tę, to w inną stronę, dopóki nie wpadła mi w ręce Dudka Macieja Buraczka: to ona mi powiedziała, że kto mówi po tutejszemu, po chłopsku, to znaczy, mówi po białorusku, a kto mówi po białorusku, ten Białorusin?'

pisała w 1906 r. klasyk literatury białoruskiej, Alojza Paszkiewicz (1876-1916), posługująca się pseudonimami literackimi: „Ciotka”, „Hauryła z Połacka”, , Maciej Krapiuka”. Jej biografka Lidia Arabiej stwierdziła, że zbiorki poezji Franciszka Bohuszewicza (18401900), pisane w języku białoruskim, „oszołomiły, ukorzyły” Alojzę Paszkiewiczankę:

Otworzył się nowy świat. Ona dotychczas nie wiedziała, jakiej jest narodowości, o oto Franciszek Bohuszewicz, Maciek Buraczok, powiedział jej to, on powiedział, że ten, kto mówi po białorusku - to Białorusin, to znaczy, i ona, Alojza Paszkiewicz, jest Białorusinką! $!^{10}$.

Zdaniem Chodubskiego identyfikacja tożsamościowa na pograniczu kultur wiąże się ze stopniem wykształcenia, a elementem najsilniej cementującym tożsamość jest język lokalny ${ }^{11}$. Dla inteligencji z pogranicza polsko-białoruskiego język białoruski był wyróżnikiem odrębności narodowej - ten, kto posługuje się językiem białoruskim, jest Białorusinem. Na przełomie XIX i XX w. Franciszek Bohuszewicz swoimi książeczkami, pisanymi w języku białoruskim „łacinką”, przekonał do białoruskiej tożsamości narodowej nie tylko Alojzę Paszkiewicz. Jego zbiorki Dudka białoruska (Kraków 1891) i Smyk białoruski (Poznań 1894), a zwłaszcza zawarte w nich przedmowy, stały się pretekstem do zastanawiania się nad świadomością narodową wśród tych, którzy się z nimi zetknęli. Stwierdzał to ksiądz Adam Stankiewicz, białoruski działacz narodowy: „słowem białoruskim, które niosło białoruską świadomość narodową w lud, była taż sama Dudka i Smyk Fr.[anciszka] Bohuszewicza"12. W przedmowach autor emocjonalnie przedstawiał swój stosunek do języka białoruskiego. Występował w jego obronie,

9 Суt. za: Л. Арабей, Стану песняй.., Мінск 1990, s. 34; Цётка, Выбраныя творы, Мінск 2001, s. 47; cytaty z języka białoruskiego, jeśli nie zaznaczono inaczej, podajemy w tłumaczeniu autorki artykułu.

10 Л. Арабей, Стану песняй..., s. 33.

11 A. Chodubski, $O$ tożsamości, s. 20-21; tenże, Swoistość kształtowania się tożsamości na pograniczach kultur, w: Europejskie dylematy i wyzwania: praca zbiorowa, red. S. Wojciechowski, Poznań 2004, s. 7-16.

12 A. Stankievič, Biełaruski chryścijanski ruch, Vilnia 1939, s. 32. 
stwierdzając, że nie jest on gorszy w porównaniu z innymi językami, że ma prawo być traktowany na równi z innymi:

Bracia mili, dzieci Ziemi-matki mojej! Wam ofiarowując pracę swą, muszę z wami porozmawiać trochę o naszej doli-niedoli, o naszym ojczystym starodawnym języku, który my sami, ale i nie tylko my, a wszyscy ludzie ciemni, „chłopskim” zwą, a nazywa się on „białoruski”. Sam kiedyś myślałem, że nasz język - język „chłopski” i tyle tego! Ale, pozdrów Boże dobrych ludzi którzy nauczyli mnie czytać-pisać, od tego czasu byłem w wielu miejscach, wiele rzeczy widziałem i czytałem: i przekonałem się, że język nasz jest taki sam ludzki i pański, jak i francuski, albo niemiecki, albo jakiś inny ${ }^{13}$.

Franciszek Bohuszewicz uznał język za istotne kryterium tożsamości narodowej, za „ubranie duszy”:

Nasz język jest dla nas święty, bo on nam od Boga dany i innym dobrym ludziom i mówimy nim wiele i dobrego, ale już tak sami puściliśmy go na poniewierkę, nie porównując, jak i wielcy panowie chętniej mówią po francusku, jak po swojemu. Nas przecież nie garstka, a około sześciu milionów - więcej i o wiele więcej, nie porównując, jak Żydów na przykład, albo Tatarów, czy Ormian, a pokaż waść choć jedną książeczkę czy o gospodarce, czy o życiu naszym, żeby była po naszemu? [...] Od wieków, jak nasza ziemia z Litwą się złączyła, jak z Polską zjednoczyła się dobrowolnie, tak zawsze „Białorusią” ją zwano i nie na darmo to! Nie wielka, nie mała, nie czerwona, nie czarna ona była, lecz biała, czysta: nikogo nie biła, nie podbijała, tylko broniła się. Wiele było takich narodów, które straciły najpierw swój język, tak jak człowiek przed skonaniem, gdy mu mowę odejmie, a potem i zupełnie zamarły. Nie porzucajcie mowy naszej białoruskiej, byście nie umarli! Poznają ludzi albo po gwarze, albo po ubraniu, kto jakie nosi; otóż gwara, język i jest ubraniem duszy ${ }^{14}$.

Bohuszewicz odwoływał się do tradycji języka białoruskiego jako urzędowego w Wielkim Księstwie Litewskim: „Czytałem czy mało starych papierów dwieście czy trzysta lat temu pisanych na naszej ziemi i pisanych przez wielkich panów, w naszym języku czyściusieńkim jakby oto teraz pisano" ${ }^{\prime 15}$. Odwołując się do historii, uświadamiał czytelnikom, że „w środku Litwy, jak to ziarno w orzechu, była nasza ziemia - Bia-

13 Dudka białaruskaja Macieja Buraczka, Kraków 1891, s. III.

14 Tamże, s. IV-V.

15 Tamże, s. III. 
łoruś!”16 Utożsamiał z nią język białoruski i zakreślał jego zasięg. „Może ktoś zapyta: gdzież obecnie Białoruś? Tam bracia, ona gdzie nasz język żyje: ona od Wilna do Mozyrza, od Witebska prawie do Czernihowa, gdzie Grodno, Mińsk, Mohylew, Wilno i wiele miasteczek i wsi..." ${ }^{17}$ - tak zakreślał terytorialnie obszar Białorusi, więc każdy potencjalny czytelnik jego Pradmowy mógł zrozumieć swoją tożsamość, sprowadzając ją do języka i konkretnego terytorium.

Chociaż Bohuszewicz proponował wyraźną odrębność językową i terytorialną Białorusi, to nie wszyscy mieszkańcy tego obszaru go czytali, aby zyskać wyraźną świadomość odrębności narodowej. Dominik Aniśko - jeden z białoruskich publicystów chadeckich, rodem z Sokólszczyzny, wspominał swoje dylematy tożsamościowe:

Ukończyłem Szkołę Miejską [w Sokółce - przyp. H. G.] w 1906 r. Jeszcze przedtem zacząłem dochodzić do białoruskiej świadomości narodowej. Bo u nas jeszcze jej nie było. Katolików nazywano „polskimi”, a prawosławnych - „ruskimi”. Ale w szkole ta terminologia już była niewystarczająca. Nawet z geografii wynikało, że na świecie żyją różne narody. Do jakiego więc należę? Do polskiego chyba nie! Bo nasz język zupełnie inny! Pewnego razu, gdy byłem w Grodnie, przechodząc ulicą Soborną, zauważyłem w oknie księgarni polskiej Białoruską Dudkę. Oczywiście, że od razu ją kupiłem. I to była pierwsza książka - białoruska! Przedmowa do tej książki bardzo mnie wzruszyła i umocniła w przekonaniu, że jestem Białorusinem ${ }^{18}$.

Białoruska świadomość narodowa rodziła się głównie wśród inteligencji i zbiedniałej szlachty, która posiadała nikłe zaplecze majątkowe i ekonomiczne. Ludność chłopska, która mogła stać się potencjalną siłą narodową białoruską, nie miała na ogół wyrobionego poczucia narodowego, utożsamiała je głównie z wyznaniem, co przyczyniało się do powstawania stereotypu: katolik - Polak, prawosławny - Białorusin. Ten dychotomiczny, uproszczony podział, wynikający z nieuświadomienia narodowego ludu, zróżnicowanego wyznaniowo, ale mówiącego jednym językiem z odmianami gwarowymi, mający odrębny od polskiego bogaty folklor, był wykorzystywany politycznie przez polskich i rosyjskich działaczy politycznych.

Trudno się dziwić chłopom, skoro wątpliwości związane z preferencjami narodowościowymi posiadali także miejscowi ziemianie. Jerzy Osmołowski zanotował we wspomnieniach swoje pytania:

16 Tamże, s. V.

17 Tamże.

18 Д. Анісько, Дамінік Анісько - аўтабіяграфія, „Божым Шляхам”, 1972, nr 1, s. 5. 
Cóż jest moją ojczyzną - Polska czy Białoruś? Kim jestem: Polakiem, czy Białorusinem? Jestem Polakiem, z kultury, języka, katolikiem, ale nie mieszkam w Polsce - mam obowiązki wobec Kraju, w którym się urodziłem, i ludzi, którzy mnie otaczają i są mi bliscy ${ }^{19}$.

O przynależności do narodów polskiego czy białoruskiego decydował często status społeczny bądź klasowy. Białorusinów postrzegano najczęściej jako warstwę chłopską, uzależnioną od ziemian i niezdolną do samodzielnego bytu narodowego. Podchodzono do nich paternalistycznie, głównie w środowisku inteligencji i ziemiaństwa o opcji krajowej.

Tadeusz Zienkiewicz zwrócił uwag̨ę na zróżnicowanie reakcji ze strony środowisk polskich na kwestię białoruską: „Zaznaczyły się trzy stanowiska: tradycjonalistyczne, eksponujące kulturalną polskość, drugie - łączące polską świadomość narodową z uznaniem prawa do istnienia innych narodowości i trzecie - głoszące program asymilacji kulturalnej i politycznej elementów niepolskich"20. Przejawami tych stanowisk był stosunek Polaków do Białorusinów. Michał Kryspin Pawlikowski po latach (po drugiej wojnie światowej, będąc na emigracji) pisał: „Dwór obywatelski był z reguły przychylny białorusczyźnie. Z chłopem rozmawiano po białorusku. Poprawne i płynne mówienie po białorusku było jakby swoistym stylem. Stąd dwory, które pod wpływem przeniesionej z zachodu zarazy endeckiej próbowały polonizować Białorusinów, były nieliczne" ${ }^{\prime 21}$. Podobne odczucia zapisał także Mieczysław Porowski: „Stosunek Polaków do Białorusinów należy określić jako wybitnie przychylny, ziemianie językiem białoruskim władali i posiłkowali się nim w stosunkach z ludem, tendencji polonizacji absolutnie nie było, przeciwnie, białorusinowała się częściowo ludność polska, zwłaszcza na wsi"22.

Stosunek społeczeństwa polskiego do białoruskiego ruchu narodowego był zróżnicowany - od postaw niechętnych i sceptycznych po szczerze przyjazne. Często nie rozumiano dążeń narodowych Białorusinów, czego powodem były występujące poglądy,

19 Biblioteka Narodowa w Warszawie, akc. 7042, k. 142, J. Osmołowski, Wspomnienia z przeszłości; cyt. za: D. Tarasiuk, Polacy białoruscy wobec idei wspótpracy narodów w latach 19051918, w: Europa unii i federacji. Idea jedności narodów i państw od średniowiecza do czasów współczesnych, red. K. Ślusarek, Kraków 2004, s. 286.

20 T. Zienkiewicz, Polskie życie literackie w Mińsku w XIX i na początku xx wieku (do roku 1921), Olsztyn 1997, s. 26.

21 M. K. Pawlikowski, Mińszczyzna, „Pamiętnik Wileński”, 1971, s. 298.

22 Cyt. za: T. Zienkiewicz, Polskie życie literackie w Mińsku, s. 26; Zakład Narodowy im. Ossolińskich we Wrocławiu, 13542/II, M. Porowski, Wspomnienia 1904-1918, rękopis, k. 16-18. 
dotyczące języka białoruskiego jako gwary przejściowej między językiem polskim a rosyjskim ${ }^{23}$. Nie uznawano języka za kryterium identyfikacji narodowej. Tak zwaną prostą mowę, którą posługiwały się szerokie rzesze mieszkańców pogranicza polsko-białoruskiego, traktowano wówczas często jako odmianę języka polskiego ${ }^{24}$. Ludność wyznania rzymskokatolickiego uważano za Polaków:

Trudność rozróżnienia ich polega na tym, że z jednej strony Polacy i Białorusini są do siebie zbliżeni pod względem językowym i religijnym. Właściwie Białorusini nie są jeszcze narodem i tylko w przyszłości, przy wielu przyjaznych warunkach mogliby może ukształtować się jako naród. [...] Niema więc słusznego powodu, abyśmy liczne rzesze włościańskie wyznania katolickiego uznawali za Białorusinów. Nawet wcale nieuświadomieni z pomiędzy nich na pytanie: jakiej są narodowości? - odpowiadają: „My tutejsi, wiary polskiej”. W ciągu dziesiątków lat walki o swoją wiarę „polską" pojęcie narodowości zrosło się w ich umyśle nierozdzielnie z pojęciem religji. [...] Za jedyną oznakę narodowości może służyć własne poczucie każdego osobnika, w razie zaś nieuświadomienia - religja, związana tradycyjnie z tą lub ową narodowością ${ }^{25}$.

Także współcześnie często stosuje się to kryterium do określenia tożsamości narodowej mieszkańców pogranicza polsko-białoruskiego ${ }^{26}$.

Witold Żukowski, autor pracy Polacy i Białorusini (Wilno 1907), uważał, że Polacy (w liczbie 722 tysięcy) w sześciu północno-zachodnich guberniach stanowią mniej więcej 1/10 ludności białoruskiej, 1/3 - litewskiej i nieco więcej niż 1/3 żydowskiej. Podkreślał przy tym, że prawie cała drobna szlachta osiadła na Białorusi, zaliczana do polskiej narodowości nie mówiła po polsku, będąc wyznania katolickiego, „zruszczała” i znajdowała się na bardzo niskim poziomie oświaty, słabo i obojętnie odnosiła się do wszystkiego, co wiązało się z polską narodowością ${ }^{27}$. Proponował deklarowanie przynależności do dwóch narodów:

23 Redakcja, W kwestii języka białoruskiego, „Kuryer Litewski”, nr 15, 18 września (1 października) 1905, s. 1. Był to odzew na artykuł A. Bohdanowicza, O języku białoruskim, „Kuryer Litewski", nr 14, 17 (30) września 1905, s. 2.

24 D. Tarasiuk, Między nadzieja, s. 16.

25 Narcyz-Ogończyk, Stosunki etnograficzne na Litwie, „Goniec Codzienny”, nr 35, 21 kwietnia (4 maja) 1910, s. 2.

26 I. Kabzińska, Wśród „kościelnych Polaków”. Wyznaczniki tożsamości etnicznej (narodowej) Polaków na Białorusi, Warszawa 1999, s. 7; kryterium to, uznając za „duże uproszczenie”, przyjął także D. Tarasiuk, Między nadzieja, s. 17.

27 W. Żukowski, Polacy i Białorusini, Wilno 1907, s. 4. 
[...] gdy postawią pytanie: „Czy jesteś pan Polakiem - czy Białorusinem?” Jestem jednym i drugim - odpowiedzą niektórzy, może większość z nas nawet. [...] I ciekawa rzecz, nas z tak zwanego kraju zabranego nazywają w Królestwie i w Polsce zakordonowej: Litwinami, Białorusinami, Ukraińcami, a na miejscu zaś - tak ludność miejscowa jak i my sami - uważani jesteśmy i uważamy samych siebie li tylko za Polaków urodzonych na Litwie lub na Rusi! ${ }^{28}$.

Szczególną rolę w uświadamianiu mieszkańców pogranicza polsko-białoruskiego odgrywała prasa, która była w znacznej większości polska. Wydawana w latach 19061915 gazeta białoruska "Nasza Niwa” odegrała również niebagatelną rolę w odrodzeniu narodowym i uświadomieniu Białorusinów. W jednym z listów do niej (z 1910 r.) niejakiego Jazepa spod Korycina - przedstawiono reakcję na nią miejscowej ludności:

Ktoś przysłał w nasze strony kilka egzemplarzy „Naszej Niwy”. Wszyscy zaczęli się wtedy nią interesować, zbierać się i głośno czytać. Po pierwsze, wszyscy się dziwili, że wychodzi gazeta, i drukują się książki w naszym ojczystym języku. A potem podniósł się wielki wrzask. Jedni mówili, że to „chamski”, brzydki język, więc lepiej czytać polskie gazety, inni znowuż (bardziej dojrzali) dowodzili, że polskim niech posługują się Polacy, a Białorusinom i białoruski język piękny ${ }^{29}$.

Redaktor i wydawca gazety Aleksander Własow pisał:

Wszystkim tym panom, którzy tak mocno chcą z Białorusinów zrobić Polaków albo Rosjan, oto co powiemy. Białoruś, jak wiadomo, leży między Polską a Wielkorosją. I z Polakami, i z Rosjanami białoruski lud stykał się z dawien dawna, tak jak i obecnie. Ze strony Rosji przychodzi do nas nie mało dobrego: wielkorusy mają swoją wielką kulturę; myśl lepszych Rosjan o wolności, o prawach człowieka, jak światło słońca, bardzo pomogły w przebudzeniu naszego kraju i chłopu-Białorusinowi z wiecznego snu, i nasz chłop się przebudził, tak samo jak chłop ruski, polski, litewski. Od kultury rosyjskiej bierzemy naukę, wiedzę obiema rękami. Co jest dobre u Rosjan, to Białorusini wprowadzają i do swego życia. Znowuż Polska także ma wielką kulturę, i Białorusinom bardzo dobrze korzystać z niej, ile można. [...] Wielu szczerych, sprawiedliwych i mądrych ludzi spośród Rosjan i Polaków bardzo współczują Białorusinom, także dlatego, że zaczęli się budzić ze snu. [...] I Białorusini, biorąc kulturę od Rosjan i od Polaków, nie powinni zapominać, że są Białorusinami, wyrzekać się własnej narodowości i przyjmować innej ${ }^{30}$.

28 Tamże, s. 6-7.

293 Беларусі і Літвы, „Наша Ніва”, nr 6, 4 (17) lutego 1910, s. 100.

30 А. Ўласаў, Вильня 25 апрыля, „Наша Нива”, nr 9, 25 kwietnia 1908, s. 2-3. 
Często na byłych ziemiach Wielkiego Księstwa litewskiego, obejmujących pogranicze polsko-białoruskie, posługiwano się dawną nazwą „Litwa” i kategorią jej obywatelstwa, określając się jako Litwin. Te pojęcia popularne na początku XX w. Leon Wasilewski wyjaśniał w kontekście historycznym i narodowym:

W zależności, od tego, kto tych wyrazów używa, zmienia się zasadniczo ich znaczenie i tu właśnie tkwi pierwsze źródło nieporozumień, z któremi mamy do czynienia na terenie Litwy. Wyraz „Litwa” bowiem można rozumieć i przeważna większość Polaków rozumie go - jako określenie całego terytorium, które dawniej mniej więcej stanowiło W. Ks. Litewskie, dziś zaś tworzy 6 guberni, t.zw. oficjalnie kraju „Północno-zachodniego”. Stojąc na tym stanowisku, „Litwinem” nazywamy każdego, kto pochodzi z ziem, wchodzących w skład jednej z wyżej wymienionych guberni. W tym znaczeniu „Litwinami” byli: Rejtan i Kościuszko, Mickiewicz i Syrokomla, Traugutt i Kalinowski, Moniuszko, Siemiradzki wraz z całą plejadą innych, większych i mniejszych postaci z dziejów polskiej umysłowości i kultury. $\mathrm{W}$ ostatnich czasach rozpowszechnia się nieco inna terminologia. Mianowicie zamiast „Litwa” mówi się „Litwa i Białoruś”, i w tym wypadku za Litwę uważa się trzy gubernie: Wileńską, Kowieńską i Grodzieńskąą.

Historyczno-administracyjne traktowanie Litwy nie przekładało się na poczucie tożsamości narodowej jej mieszkańców. Złożoność stosunków etniczno-narodowościowych na Litwie i Białorusi wynikała z niskiej świadomości narodowej znacznej części ludności Litwy

[...] i to nie tylko warstw ludowych, lecz i inteligiencji. Na Litwie można spotkać człowieka, uważającego się za najlepszego Litwina, a mimo to wrogo traktującego ruch litewsko-żmudzki, można tam spotkać ludzi nie umiejących po polsku, a jednak z całą stanowczością przyznających się do narodowości polskiej, można też zetknąć się z masą, która wie, że jest „katolicką" i w żaden sposób nie potrafi określić bliżej swej przynależności narodowościowej. Tylko na Litwie codziennie spotykamy się z takiemi zjawiskami, jak to, że osobistości, noszące nazwiska Wiłejszysów lub Dowojnów-Sylwestrowiczów, należą i do obozu antypolsko usposobionych narodowców litewsko-żmudzkich i do obozu polsko-narodowo-demokratycznego, że fanatyzmem polskim tchną ludzie o niewątpliwie litewsko-żmudzkim pochodzeniu i nazwisku, gdy, przeciwnie, szowinizm antypolski cechuje Polaków wychodźców z Mazowsza, ludzi, kulturalnie wchodzących do narodowości polskiej².

31 L. Wasilewski, Litwa i Białoruś. Przeszłość - teraźniejszość - tendencje rozwojowe, Kraków [1912], s. XIII-XIV.

32 Tamże, s. XIV-XV. 
Takie skomplikowane opcje narodowościowe zdarzały się w wykształconych rodzinach ziemiańskich, czego przykładem była rodzina Iwanowskich z majątku Lebiodka koło Lidy - wśród czwórki braci Stanisław i Jerzy uważali się za Polaków, Wacław za Białorusina a Tadeusz - za Litwina, podczas gdy ich ojciec Leonard uważał się za Litwina w sensie historycznym, za obywatela Wielkiego Księstwa Litewskiego $0^{33}$. Jerzy Turonek tak skomplikowane dylematy tożsamościowe tłumaczy sukcesją po Wielkim Księstwie Litewskim, w którym ukształtowała się polityczna litewskość jako kategoria obywatelstwa. Po jego rozpadzie, różne opcje narodowościowe były dość często spotykane, nawet w tej samej rodzinie - polsko-białoruskie opcje Skirmuntów, Kostrowickich, Bohuszewiczów czy polsko-litewskie Romerów, Tyszkiewiczów, Miłoszów. Było to wynikiem losów trzech narodów i trzech kultur, które potoczyły się własnymi drogami, na które wkroczyli potomkowie wielkolitewskich rodzin. Józef Mackiewicz przedstawił taką skomplikowaną sytuację:

Bo ciocia Pafcia wyszła za mąż za Litwina jeszcze w czasach, gdy wszyscy mieszkańcy b. W. Księstwa Litewskiego nazywali sami siebie Litwinami. Ale już w czasie dorastania Henryka część ich zaczęto przezywać „Litwomanami”. Wtedy Litwini zaczęli nazywać się Polakami, a Litwomani Litwinami. Rzecz wydała się dość zawiła, a w szczegółach nieprzyjemna. - Mamo - zapytał - czy ciocia Pafcia jest Liwomanką, Litwinką czy Litwinką Polką, ale nie Litwinką? $?^{34}$.

Piotr Zubowicz na łamach „Pracy” (dodatku do „Biblioteki Warszawskiej”) wskazywał na specyfikę Białorusi:

Białoruś w zaraniu dziejów historycznych utraciła samodzielność państwową i nigdy nie występowała na arenie politycznej, jako samodzielna jednostka, wiążąc zawsze swe losy z losami innych narodów, od których znajdowała się w zależności - to musiało wpłynąc na charakter rozwoju tego kraju, nie posiadającego własnej historii i do ostatnich dni będącego objektem sporu rywalizujących wpływów obcych. Już w XIII stuleciu Białoruś podlega zwierzchniczej władzy książąt litewskich. Wybujałość rozrostu państwowego osłabiła odporność Litwy na wpływy kulturalne, energia twórcza została wyczerpaną w ekspansji państwowej i kultura białorusińska w dobie owej nie uległa litwinizacyi, lecz powoli zdobyła sobie prawo obywatelstwa na dworach książęcych, wielkich bojarów w miastach i miasteczkach państwa litew-

33 J. Turonek, Wacław Iwanowski i odrodzenie Białorusi, Warszawa 1992, s. 7-22.

34 J. Mackiewicz, Pod każdym niebem, Londyn 1964, s. 15. 
skiego. Pierwiastki słowiańskie zaczęły przenikać do kultury litewskiej i wkrótce przeważyły w niej, wywalczając sobie dominujące stanowisko. Język białoruski raczej narzecze krywiczańskie, wkracza do aktów rządowych i staje się językiem państwowym. Nie tylko przed Unią, lecz nawet w parę wieków po Unii język białoruski był uważany w Wielkiem Księstwie Litewskiem za język urzędowy i wyłącznie używany w dokumentach publicznych. Gdy król Zygmunt I polecił panom litewskim, aby pod przewodnictwem kanclerza Alberta Gasztołda zebrali dawne uchwały i stare prawa zwyczajowe w jeden statut, spisano go w języku białoruskim, a dopiero później przetłumaczono na łacinęi polski. W statucie owym, zwanym powszechnie „Litewskim”, zawarowanem zostało, że sędziowie na Litwie i Białorusi muszą koniecznie znać język białoruski. „A pisarz ziemski ma po Rusku literami y słowy Ruskiemi wszystkie listy, wypisy y pozwy pisać, a nie inszym językiem y słowy". [...] Z biegiem czasu wpływ kultury białoruskiej w Wielkiem Księstwie Litewskiem słabnie. Naturalną ewolucyą proces polonizacyjny robił postępy bardzo wyraźne i spychał język białoruski z uprzywilejowanego stanowiska. [...] Był to jednak proces bezwiedny i niema najmniejszych śladów, aby sfery rządzące kiedykolwiek dążyły do świadomej polonizacyi krajów, przynależnych do Rzeczypospolitej. [...] Nastąpiło zupełne nietylko polityczne lecz i kulturalne zlanie się szlachty litewskiej i ruskiej ze szlachtą polską. Asymilacya ta jednak nie sięgnęła głęboko, polonizowały się oprócz dworów i dworków jedynie miasta i miasteczka, skąd kultura polska promieniowała wewnątrz kraju, tworząc wyspy i wysepki polskie na jednolitem morzu ludowem litewskiem lub ruskiem. Lud przechował szczupłe i ubogie pierwiastki rodzimej kultury i pozostał na straży rodzimych tradycyj ${ }^{35}$.

Piotr Zubowicz wskazywał na trudności w wyznaczeniu linii osadnictwa białoruskiego:

Nakreślić linię demarkacyjną siedzib białoruskich obecnie jeszcze nie jest możliwem ze względu na nizki stopień uświadomienia narodowego wśród szerokich mas ludu i stopniowego wynaradawiania się na kresach etnograficznej ludności białoruskiej. Dotąd bowiem odbywa się jeszcze proces zacieśniania się granic Białorusi: ciągłe sąsiedzkie stosunki w ciągu wieków zacierały coraz bardziej plemienne i językowe różnice, a wpływy kulturalne i religijne wniosły do ogólnego tła ludu różnice lokalne tak, że obecna Białoruś rozpada się na kilka dzielnic, mających znaczne różnice pod względem wyznaniowym, obyczajowym, a w znacznej mierze i językowym. Narzecze białoruskie rozpada się na gwary, z których jedne są podobniejsze do języka rosyjskiego - na wschodnich i północnych kresach Białorusi; drugie, do Rusińskiego - na południu gub. Mińskiej i Grodzieńskiej; trzecie

35 P. Zubowicz, Białoruś i Białorusini, „Praca”, 1910, nr 1, s. 1-3. 
wreszcie, do polskiego - na zachodzie. Ponieważ po białorusku mówi przeważnie tylko brać siermiężna, przeto Białorusini, stykając się z ludnością miejską i inteligencyą, zapożyczają od niej wyrazy pojęć nieznanych w zwykłem życiu wioskowem. Tam, gdzie po miastach i wśród inteligencyi przeważa język rosyjski, Białorusini przejmują do swej mowy dużo rusycyzmów. Tam, gdzie się częściej stykają z Polakami, mowa ich ulega znacznemu wpływowi języka polskiego. Wpływ rosyjski silniejszym jest wśród Białorusinów, wyznawców prawosławia, polski u wyznawców katolicyzmu, którzy modlą się, słuchają kazań i śpiewają w kościołach po polsku ${ }^{36}$.

Piotr Zubowicz wyraźnie dostrzegał rozwój ruchu białoruskiego i duże w tym znaczenie „Naszej Niwy”: „Świadomość ludowa uczyniła pewien postęp, hasła białoruskie znalazły oddźwięk pod strzechą chłopską, czego dowodem mogą być liczne korespondencje chłopskie z różnych okolic, umieszczane w «Naszej Niwie»" ${ }^{\text {37 }}$. Dylematy tożsamościowe według niego wynikały z niskiego uświadomienia narodowego ludu. Podając przykład Wileńszczyzny, pisał:

Białoruś wileńska jest w znacznej mierze spolonizowana i pod względem kulturalnym ciąży widocznie do tradycyj historycznych. [...] Trzeba przyjąć pod uwagę, że w tej części kraju zupełnie jeszcze nie jest skrystalizowane pojęcie narodowości i że wielu włościan nie umie na to pytanie odpowiedzieć. Badając tameczne stosunki, nieraz zwracałem się do miejscowych ludzi, stawiając im kategoryczne zapytanie, jakiej są narodowości - i odpowiadano mi gęsto „tutejszej”, „polackiej wiary”, „ruskiej wiary". Gdym pragnął dostać się do jądra rzeczy i zapytywałem, w jakim języku mówią w domu, określano mi, że „po prostemu”. Nie trzeba więc nawet posądzać o złą wolę tych, co pełnili w tych stronach czynności spisu, gdyż wypełnienie rubryki narodowościowej, wskutek wyżej wspomnianych przyczyn, napotykało zapewne niemało trudności i stąd też w wielu miejscowościach całą ludność z wyjątkiem inteligencyi ryczałtowo zapisywano jako Białorusinów ${ }^{38}$.

Wymownie świadczy o tym jedna z korespondencji do białoruskiego tygodnika katolickiego „Biełarus” z miasteczka Kiemieliszki na Wileńszczyźnie:

Lud tu tylko katolicki, mówi po białorusku, ale więcej-źle po polsku, co niedzieli zbiera się wiele ludzi w kościele, z czego można sądzić, że lud ten jest nabożny.

36 Tamże, s. 6.

37 Tamże, s. 18.

38 Tamże s. 6-9. 
[...] Gazet tu u nas prawie się nie czyta, a książka białoruska, czy gazeta tutaj to wielka nowina ${ }^{39}$.

Pozornie w kościele katolickim problem języka białoruskiego, zgodnie z ukazami carskimi i decyzjami watykańskimi, miał być rozwiązany zgodnie z zasadą używanego języka w życiu codziennym. 22 sierpnia 1905 r. biskup wileński ks. Edward Ropp wydał księżom prefektom okólnik, w którym określał, że

[...] modlitwy, katechizm, historię św., historię Kościoła w szkołach wykładać należy w tym języku, w którym młodzież modli się w domu, tj. po polsku lub po litewsku. Dzieciom białorusińskim, w szkołach początkowych na wypadek konieczności można wyjaśniać przedmiot wykładany po białorusińsku ${ }^{40}$.

Poza epizodycznymi przypadkami na ziemiach białoruskich nie istniała białoruska tradycja katolicka. Miejscowi duchowni katoliccy najczęściej uważali się za Polaków i językiem polskim posługiwali się w kazaniach i katechizacji, upowszechniając przy tym polską świadomość narodową, zgodną z funkcjonującym stereotypem „jak katolik to Polak". W związku z tym w środowisku ludności katolickiej białoruskość przyjmowano z dystansem, jako coś nowego, niemal rewolucyjnego. Większość księży deklarowała narodowość polską i nie widziała potrzeby posługiwania się językiem białoruskim. Wierni zaś często utożsamiali się z polskością, skoro charakter sakralny dla nich miał język polski w Kościele. Język białoruski był językiem codziennej komunikacji. Niewielka liczba księży Białorusinów czyniła starania w zakresie upowszechniania języka białoruskiego w kazaniach, katechizacji i w wydawnictwach religijnych oraz działała na rzecz uświadomienia narodowego wiernych w kierunku białoruskości.

W 1911 r. Anton Łuckiewicz, jeden z ideologów ruchu białoruskiego, w pracy Na darozie da novaha żyćcia uważył, że głównym wrogiem ruchu białoruskiego są księża Polacy. Zarzucał im polonizację ludności katolickiej na ziemiach białoruskich:

[...] duchowieństwo katolickie, używając w kościele w dodatkowych modlitwach i kazaniach tylko języka polskiego i bez pomocy rządu zupełnie w naturalny sposób polonizowało i polonizuje Białorusinów-katolików. Z teg̉o wszystkiego oto co wyszło. Chłop białoruski, nie rozumiejąc, czym katolicyzm różni się od prawosławia,

39 Jazepka S. z Z., Miasteczka Kiemieliszki, „Biełarus”, nr 27, 3 lipca 1914, s. 5.

40 Za: M. Moroz, „Krynica”. Ideologia u przywódcy białoruskiego katolicyzmu, Białystok 2001, s. 36. 
mocno wierzy, niby katolicyzm - to polska wiara, prawosławie - rosyjska. I zadziwiające: w cerkwi on przyzwyczaił się słyszeć język rosyjski, w kościele - polski, własnego macierzystego, białoruskiego, nie słyszy ani tu, ani tam. Polityka rządu i duchowieństwa doprowadziła do tego, że dwa zupełnie odrębne pojęcia - nacji i religii - w głowie Białorusina zlewają się w jedno. „Polak” i „katolik” dla niego takie same synonimy, jak „ruski”, „Rosjanin” i „prawosławny” ${ }^{\text {. }}$.

Stanowisko Antoniego Łuckiewicza spotkało się z ostrym sprzeciwem, m.in. ks. Witolda Czeczotta, który stwierdzał, że

u białorusinów tej świadomości niema, i kwestja odrębności ich języka i narodowości zaledwie budzić się zaczyna. Ale ta garstka inteligientów, nie z ich sfery pochodząca, co ruch ten zapoczątkowała występuje z pretensją do Polaków, współrodaków swoich, że stłumili kulturę białoruską, którą wskrzesić zamierzają ${ }^{42}$.

Jako argumentu używał utrwalonego status quo:

Każdego, kto był w kościele parafjalnym katolickim na Białej Rusi, musiał uderzyć fakt, że tam, zupełnie tak samo jak w Królestwie, w Galicji, w Poznańskiem lud czynny bierze udział w nabożeństwie. Śpiewa Różaniec, Godzinki, Gorzkie Żale, Suplikacje, Kolendy i różne pieśni kościelne stosownie do części roku kościelnego. Wszystko to śpiewa czysto po polsku - w tym języku pacierz mówi, tak w kościele jak i w domu; po polsku też matki uczą dzieci katechizmu, książki do nabożeństwa jeśli ma - to także wyłącznie polskie - choć poza kościołem, tak między sobą jak i w stosunku do obcych używają narzecza białoruskiego. Na zapytanie jakiej jest wiary? - najczęściej odpowiada polskiej, ale siebie samego ma nie za Polaka lecz za tutejszego (krajowca). [...] Podobieństwo języka białoruskiego do polskiego [...] ułatwiło wzajemne zbliżenie i porozumienie, tak że z czasem Białorusin zaczął uważać język polski niejako za liturgiczny, kościelny, którym wyłącznie rozmawiał z Bogiem i zaspokajał potrzeby swojej duszy, i stąd i wiarę swą nazywać zaczął polską. Źle się stało, że duchowieństwo parafjalne na Białej Rusi poprzestało na tym polskim pokoście, i nie zwróciło uwagi, że chłopek co tak pobożnie pieśni śpiewa, i tak uważnie na pozór kazania słucha - w istocie mało co z tego rozumie ${ }^{43}$.

41 А. Луцкевіч, На дарозе да новага жыцьця, w: tenże, Да гісторыі Беларускага руху, Мінск 2003, s. 55 .

42 X. W. Czeczott, Około kwestji białoruskiej, „Litwa i Ruś”, 6 (1913) s. 5.

43 Tamże, s. 7-8. 
Zwracał uwagę, że ani „Nasza Niwa”, ani Dudka białoruska nie cieszyły się zbytnią popularnością wśród włościan białoruskich, co świadczyło o ich niskiej świadomości narodowej:

Próbowałem kilkakrotnie dawać do czytania chłopakom umiejącym czytać biegle po polsku i rosyjsku „Dudkę białoruską” - Bohuszewicza - żaden z nich nie umiał się zorjentować w swej rodzimej mowie w szatę druku przyodzianej. [...] Wątpliwą jest rzeczą czy lud dzisiejszy oceniłby dobrodziejstwo, jakie mu nacjonaliści chcą wyświadczyć, ucząc go ich własnego narzecza zamiast kulturalnego języka polskiego. Wówczas kiedy można było zakładać szkółki wiejskie na Litwie, uczono w nich po polsku. Dzisiejsi ultrapatrjoci widzą w tem gwałt zadany rodzimej kulturze, i narzekają na polonizację. Gdyby jednak spytano ówczesnego wieśniaka, czy chce, aby jego dzieci uczono po polsku czy po białorusku, nie zawahałby się wybrać pierwsze, bo jego chłopski rozum podszepnąłby mu zaraz, że polski utoruje mu drogę na świecie, że będzie kluczem do kultury już wyrobionej i bogatej literatury, że rozszerzy horyzont jego ducha - „Prostego mego języka, pomyśli zapewne, uczyć się nie mam poco; umiem go o tyle, o ile w życiu codziennem potrzebny, a poza tem - na cóż mi się przyda?"44.

W okresie międzywojennym pogranicze polsko-białoruskie znajdowało się na Kresach północno-wschodnich Drugiej Rzeczypospolitej (II RP). Dylematy tożsamościowe były uzależnione wówczas w znacznej mierze od polityki państwa polskiego w stosunku do mniejszości narodowych. Odpowiedzią na zróżnicowanie narodowościowe miały być spisy powszechne ludności. Alfons Krysiński uznawał, że „obliczenie ilości Białorusinów i ustalenie białoruskiego obszaru etnograficznego w granicach Rzeczypospolitej Polskiej należy do najtrudniejszych zagadnień w dziedzinie spraw narodowościowych"45. Powodów takich trudności było kilka:

jeszcze nie tak dawno świadomość narodowa u Białorusinów prawie zupełnie nie istniała: znaczna część ludności białoruskiej swej przynależności narodowej zupełnie nie umiała określić, oznaczając ją jako „tutejszą”, „miejscową”, lub też podając zamiast narodowości wyznanie. Z drugiej strony wyznaczenie granicy obszarów językowych na kresach północno-wschodnich jest znacznie trudniejsze, niż na przykład na południowym-wschodzie, gdzie brak jest zupełnie gwar

44 Tamże, s. 11.

45 A. Krysiński, Liczba i rozmieszczenie Białorusinów w Polsce, „Sprawy Narodowościowe”, 2 (1928) nr 3-4, s. 351. 
przejściowych pomiędzy obszarami polskim i ukraińskim. Na rubieżach białoruskiego obszaru językowego przeciwnie istnieją całe pasy dialektologicznie pośrednie, gdzie lud mówi narzeczem mieszanem polsko-białoruskiem (obwód białostocki) lub ukraińsko-białoruskiem (część dorzecza Prypeci). Wreszcie, gdy na południu o narodowości stanowi właściwie wyznanie czy też obrządek, tu, np. wśród katolików mamy Polaków, Litwinów i Białorusinów. Wszystkie te przyczyny sprawiają, iż poglądy na ilość Białorusinów oraz na rozmiary obszaru etnograficznego białoruskiego w Polsce są rozbieżne ${ }^{46}$.

Alfons Krysiński, badając liczbę i rozmieszczenie Białorusinów w województwach północno-wschodnich II RP, zakwestionował przede wszystkim wiarygodność urzędowego spisu ludności z 30 września 1921 r., wskazującego na 32,2\% (1 041000) Białorusinów i 52,9\% (1 708 ooo) Polaków ${ }^{47}$. Stwierdzał, że „poważni badacze polscy przyznają, iż liczba Białorusinów w Polsce jest większa od podanej przez spis i odpowiednio korygują jego wyniki” ${ }^{48}$. Uwzględniając różne procesy, liczbę Białorusinów na 1 stycznia 1928 r. ustalił na 1590000 dusz $^{49}$. Stanowić to miało około 40\% mieszkańców tych ziem. Był to jeden z wariantowych szacunków, który stworzył precedens do podważania oficjalnych wyników spisu.

Białoruscy publicyści zwracali uwagę na świadome zafałszowania podczas spisu:

Oto w powiecie baranowickim komisarze spisowi zpośród nauczycielstwa zadawali katolikom Białorusinom pytania nie o język macierzysty, ale o język modlitwy, wiedząc doskonale, iż ci modlą się po polsku. W niektórych miejscowościach powiatu dziśnieńskiego pomimo protestu rodziców zapisywano dzieci w wieku szkolnym jako posługujące się ojczystym językiem polskim, ponieważ chodzą do polskiej szkoły. W powiecie wileńskim żądano przy spisie dokumentów potwierdzających narodowość białoruską. W powiecie wileńsko-trockim [...] wprost grożono represjami za ujawnianie języka białoruskiego [...]. Piszący te słowa przed kilkoma dniami słyszał na własne uszy wynurzenia pewnej nauczycielki znad granicy bolszewickiej. Z dumą godną lepszej sprawy chwaliła się ona w licznie zebranem towarzystwie, iż wszystkim Białorusinom wpisała język polski jako ojczysty ${ }^{50}$.

46 Tamże, s. 352

47 Tamże, s. 353; Piotr Eberhardt podaje, że spis ludności odbył się w grudniu 1921 r.: P. Eberhardt, Przemiany narodowościowe na Białorusi, Warszawa [1994], s. 57.

48 A. Krysiński, Liczba i rozmieszczenie Białorusinów w Polsce, s. 353-354.

49 Tamże, s. 379.

50 Al. S., Po spisie, „Przegląd Wileński”, 1932, nr 1-2, s. 6-7. 
Wiarygodność spisów powszechnych w Drugiej Rzeczypospolitej podważał też badacz kwestii narodowościowych Seweryn Wysłouch:

Statystyka narodowościowa powszechnych spisów z 1921 i 1931 roku nie była w stanie kwestyj tych rozwiązać w sposób jasny i nie budzący poważnych wątpliwości. Pogorszyło sprawę usiłowanie przedstawienia tych stosunków w sposób jak najbardziej „korzystny” dla polskiego stanu posiadania, co jeszcze bardziej zaciemniło i tak dostatecznie pogmatwaną sprawę. Ostatecznie otrzymaliśmy cyfry podziału narodowościowego ludności Ziem Północno-Wschodnich Rzeczypospolitej, które moim zdaniem dalekie są od wyjaśnienia istotnego stanu rzeczy ${ }^{51}$.

Tłumaczył to dalej:

Przy pierwszym spisie z 30 września 1921 roku pytano ludność i o narodowość i o język, ale ogłoszone zostały tylko wyniki dotyczące narodowości. Narodowość przytem pojmowano nie jako sumę cech kulturalnych i naturalnych, które czynią dane jednostki podobnymi do siebie i różnymi w stosunku jednostek innych narodowości o odrębnych cechach i właściwościach, lecz jako podmiotową ocenę zainteresowanej jednostki, czyli opartą na jej świadomości narodowej. Stojąc na gruncie plebiscytu narodowościowego spis $1921 \mathrm{r}$. nie przewidywał stanów faktycznych, w których jednostka nie będzie umiała określić swej przynależności narodowej. Ponieważ [...] stopień uświadomienia narodowego szerokich mas włościaństwa kresowego jest bardzo niski, odnośne rubryki wypełniali według własnego widzimisię komisarze spisowi. Drugi powszechny spis ludności z dn. 9 grudnia $1931 \mathrm{r}$. uwzględniał tylko język ludności. Kryterium to w zasadzie przesuwa ciężar zagadnienia z elementów podmiotowych na elementy przedmiotowe. W ten sposób wydawać by się mogło, że wyniki tego spisu będą bardziej obiektywne i wiarygodne niż spisu 1921 r. Niestety tak nie jest. Przede wszystkim w ogromnej większości komisarze spisowi, wychodząc ze źle pojętego „interesu polskiej racji stanu”, wpisywali jako język ludności białoruskiej - język polski. W stosunku do ludności katolickiej za kryterium języka ojczystego przyjmowano język, w którym się modli, t.zn. język polski. Poza tym wątpliwości budził język potoczny ludności białoruskiej t.zw. język prosty, który domorośli lingwiści oceniali jako „skażony język polski". Wreszcie tam, gdzie ludność nie obstawała przy języku białoruskim z reguły wpisywano jako ojczysty język polski. Jeśli się równocześnie zważy na nacisk administracji państwowej, a w owym czasie przeczącej w ogóle sam fakt

51 Zakład Narodowy im. Ossolińskich we Wrocławiu, S. Wysłouch, Stosunki narodowościowe na terenie województw wschodnich a spisy ludnościowe 1921 i 1931 r., (maszynopis), s. 1; w 2013 r. Studium Europy Wschodniej Uniwersytetu Warszawskiego wydało tę pracę: Stosunki narodowościowe na terenie województw wschodnich, Warszawa 2013, s. 3-4. 
istnienia Białorusinów w Polsce, łatwy stąd wniosek jak dalekie od rzeczywistości były wyniki spisu $1931 \mathrm{r}$. [...] Spis $1931 \mathrm{r}$. posiadał na interesującym nas terytorium charakter plebiscytu narodowościowego. Natomiast nie uwzględniał on podobnie jak spis 1921 r. stanów faktycznych, przy których jednostka nie umiała określić swej przynależności narodowościowej, co tu było równoznaczne z niemożnością nazwania języka potocznego, jakim się posługiwała ${ }^{52}$.

W 1937 r. Seweryn Wysłouch przeprowadził badania terenowe w 52 wsiach powiatu wileńsko-trockiego i oszmiańskiego, w wyniku których wykazał ewidentne braki spisów ludnościowych ${ }^{53}$. Wyniki swoich badań skonfrontował z wynikami spisu powszechnego z 1931 r. Uważał, że okazały się one zupełnie inne, wykazując przede wszystkim niedojrzałość do identyfikacji narodowej ludności, która najczęściej z polskością identyfikowała wyznanie katolickie i przynależność państwową, stwierdzając: „Jak mieszkamy w Polsce, to jesteśmy Polakami" ${ }^{54}$. Na przykład we wsi Kule w gminie Szumsk na Wileńszczyźnie na ogólną liczbę ludności 158 w 1931 r. język białoruski jako ojczysty podały 143 osoby. Według ankiet Wysłoucha okazało się, że we wsi brak uświadomienia narodowego: „Ludność nie odróżnia wyznania od narodowości. Twierdzi, że jest polską tylko dlatego, że jest katolicką. Między sobą rozmawia «po prostu». Do ruchu białoruskiego jest ustosunkowana podejrzliwie" ${ }^{\prime \prime 5}$. We wsi Ulany w tej samej gminie, gdzie według spisu 1931 r. było 83 mieszkańców i wszyscy zadeklarowali język białoruski jako ojczysty, w 1937 r. ludność identyfikowała narodowość z wyznaniem: „Za Białorusinów jednak ludność nie chce uchodzić, mimo że stale używa języka «prostego». Białorusinów uważa za coś niższego od Polaków" ${ }^{156}$. W konkluzji na podstawie przeprowadzonych badań Seweryn Wysłouch stwierdzał:

[...] ogromna większość mieszkańców badanego terenu nie jest albo wcale uświadomiona narodowo, albo bardzo słabo. [...] Przede wszystkim w niektórych zbadanych miejscowościach dotychczas spotykamy się z objawami indyferentyzmu narodowego. Po prostu ludność nie przywiązuje wagi do kwestii swej przynależności narodowościowej. Tak np. ludność wsi Kokniszki, gm. Szumskiej „nie przywiązuje do tego większej wagi i nad sprawą narodowościową głębiej się nie zasta-

52 Maszynopis, s. 2-3; wyd. z 2013 r., s. 4-5.

53 Maszynopis, s. 8; wyd. z 2013 r., s. 9.

54 Maszynopis, s. 13; wyd. z 2013 r., s. 11.

55 Maszynopis, s. 10-11; wyd. z 2013 r., s. 10.

56 Maszynopis, s. 11, wyd. z 2013 r., s. 10. 
nawia. Powiadają: „należymy do Polski, więc jesteśmy Polakami”. [...] Najczęściej ludność na pytanie o swej przynależności narodowej usiłuje dać odpowiedź pozytywną, opierając się przytem na dość charakterystycznym rozumowaniu. Najczęstszym kryterium, na jakim opiera ludność swą przynależność narodowościową jest wyznanie. Typowa odpowiedź ankiety w tym względzie głosi: „słabo uświadomieni Polacy, identyfikują wyznanie z narodowością i za Białorusinów (ruskich) uważają tylko prawosławnych. W rozmowach między sobą używają języka „prostego". [...] Obok wyznania kryterium, na którym dość często ludność opiera swą świadomość narodowościową polską, jest przynależność państwowa polska, lub zamieszkanie na terenie Polski ${ }^{57}$.

Zestawiając wyniki spisów ludnościowych z 1921 r. i 1931 r. z przeprowadzonymi badaniami terenowymi na wybranym terenie, Wysłouch stwierdzał, że de facto stały one na gruncie plebiscytu narodowościowego, opierając się na stosunku podmiotowym jednostki do swojej narodowości. Brakowało w nich rubryki dla ludności beznarodowej, mającej problem z określeniem swej narodowości, co w konsekwencji spowodowało dowolne wpisywanie przez komisarzy spisowych narodowości polskiej lub białoruskiej według własnego widzimisię. Sprowadzało to absolutną dowolność i niewiarygodność obrazu stosunków narodowościowych w ujęciu wspomnianych spisów:

Cyfra ludności polskiej jest niewątpliwie wyolbrzymiona. Stanowczo należy odrzucić wszelkie pomysły w rodzaju „Polaków prawosławnych” na wsi kresowej. Również nie można uważać całej ludności katolickiej (prócz Litwinów) za polską. Co najwyżej możemy uznać, że jest to ludność odnosząca się bardziej życzliwie do polskości niż prawosławna. Również nie odpowiada rzeczywistości cyfra obrazująca liczbę Białorusinów w Polsce. Jeśli stoimy na gruncie świadomości narodowej wśród ludu białoruskiego będzie ona za duża, natomiast jeśli oprzemy się na kryterium języka ojczystego, niewątpliwie jest za mała ${ }^{58}$.

Wysłouch uważał, że badając skład narodowościowy ludności na ziemiach północno-wschodnich, należy przyjąć za "fundamentum divisionis kwestię: języka, wyznania, uświadomienia narodowego, o ile ono się przejawia, i wreszcie stosunek ludności do polskości i państwa polskiego" ${ }^{\prime 59}$. Badając ludność wiejską w województwiach

57 Maszynopis, s. 19-20; wyd. z 2013 r., s. 16-17.

58 Maszynopis, s. 21; wyd. z 2013 r., s. 18.

59 Maszynopis, s. 8; wyd. z 2013 r., s. 25. 
wileńskim (powiaty święciański, postawski, dziśnieński, wilejski, mołodeczański) i nowogródzkim (powiaty nowogródzki, szczuczyński, stołpecki, lidzki), Wysłouch wskazywał na trudności związane z określeniem narodowości przez miejscową ludność, bowiem jej duży odłam nie miał

[...] żadnego uświadomienia narodowego. [...] Na pytanie o przynależność narodową ludność najczęściej odpowiada: „A chto jeho wiedaje, jazyk to u nas prosty my tutejsze", albo - „Jak byli pod Ruskim to hawaryli szto my Biełarusy, a ciapier piszu szto my Palaki". Są to odpowiedzi typowe; charakteryzują one nie tylko kompletny brak uświadomienia narodowego, lecz również brak zainteresowania sprawami narodowościowymi. Dla chłopa "tutejszego" kwestia ta jest rzeczą nieistotną, nie mającą żadnego praktycznego znaczenia. Oto charakterystyczna odpowiedź chłopa: „Nazywaj nas pan choć Niemcem, tylko żeb’ żyć było trochi lahczej ${ }^{60}$.

Jak była to zagmatwana sprawa nawet dla badacza kwestii narodowościowej w województwach północno-wschodnich II RP, świadczy istotne spostrzeżenie Seweryna Wysłoucha:

Chłopi bardzo często wypowiadają się wobec obcych o swej narodowości nieszczerze. W duchu uważają się za Białorusinów, lecz nie zdradzają się z tym oficjalnie, bojąc się jakichkolwiek represyj ze strony władz miejscowych, które w Białorusinie, jak informują ankiety, widzą częstokroć komunistę i prześladują go potem, wszczynając dochodzenia policyjne za najmniejsze podejrzenie i stosując na szeroką skalę szykany. Tego rodzaju metody powodują wśród chłopów wielką bojaźń do wszelkiego rodzaju zwierzeń się i szczerych zeznań. Np. zasadą ludności wsi Bojary, gm. wasiliskiej, pow. szczuczyńskiego jest podawanie się za takich, jacy się podobają czynnikom rządowym. Oto mieszkańcy wsi Bakszty, gm. wasiliskiej pow. szczuczyńskiego podają się oficjalnie za Polaków, w rzeczywistości w rozmowach ze sobą nazywają się Białorusinami ${ }^{61}$.

Wysłouch scharakteryzował poszczególne grupy narodowe na badanym przez siebie terenie. Za Polaków uznawał potomków dawnej szlachty zaściankowej, często nieróżniących się wcale od okolicznego włościaństwa, ale wyróżniających się wyraźną świadomością narodową, nawiązującą do tradycji szlacheckiej i powstań narodowych, posługiwaniem się językiem polskim (często także białoruskim) oraz wyznaniem rzym-

60 Maszynopis, s. 5; wyd. z 2013 r., s. 22-23.

61 Maszynopis, s. 5-6; wyd. z 2013 r., s. 23. 
skokatolickim. Ich liczbę szacował na terenie badań na około 5\% mieszkańców ${ }^{62}$. Charakteryzując Białorusinów, określał ich jako najliczniejszą grupę narodowościową, zamieszkującą województwa północno-wschodnie:

Z górą 90\% ludności miejscowej mówi językiem białoruskim, jednakże wśród niej wyłania się element, dla którego język jest nie tylko środkiem porozumiewawczym, lecz jest wyrazem świadomej odrębności narodowej, podkreślonej odmiennością wyznania i nieraz wrogim stosunkiem do polskości i państwa polskiego. Są to uświadomieni Białorusini ${ }^{63}$.

O świadomości białoruskiej decydowały następujące czynniki: powstanie inteligencji białoruskiej, działalność organizacji białoruskich, agitacja komunistyczna ${ }^{64}$.

Ciekawym spostrzeżeniem Wysłoucha było to, że niemal każda wieś białoruska uświadomiona posiadała po kilka lub kilkanaście osób miejscowej inteligencji, podczas gdy wsie zamieszkałe przez tzw. ludność „tutejszą" z reguły jej nie posiadały ${ }^{65}$. W wyniku przeprowadzonych badań okazało się, że najbardziej wrogo ludność białoruską do państwa polskiego nastrajały ciągłe represje i szykany policji (protokoły, mandaty karne, areszty gminne). Także władze administracji ogólnej i samorządy miejscowe, obsadzane z reguły obcymi ludźmi, którzy odnosili się do chłopa jak do „ciemnego chama”, nie sprzyjały kreowaniu pozytywnego stosunku Białorusinów do państwa polskiego: „sekretarz gminy jest wielkim panem, który nieraz interesantów wyrzuca za drzwi i pobiera, w mniemaniu chłopów, dużą pensję ${ }^{\text {n6 }}$.

Seweryn Wysłouch wskazywał na nierówności ekonomiczne i klasowe, które bardziej formowały świadomość ludności niż kryteria narodowościowe. Te również zdaniem Wysłoucha bywały traktowane koniunkturalnie:

Duży odłam ludności „tutejszej”, uważającej się za Polaków, spekuluje po prostu przynależnością narodową dla celów utylitarnych - im się po prostu kalkuluje ogłosić siebie za Polaków, ponieważ przez to unikną szykan ze strony władz administracyjnych i mogą uzyskać pewne przywileje. „Na czyim wozie jedziesz, tamu piesieńku śpiewaj" - powiadają mieszkańcy wsi Gaudziszki, gm. Nowodworskiej, pow. szczuczyńskiego, którzy zdają sobie sprawę, że są Białorusinami, lecz

62 Maszynopis, s. 10; wyd. z 2013 r., s. 27.

63 Maszynopis, s. 12; wyd. z 2013 r., s. 28.

64 Tamże.

65 Tamże.

66 Maszynopis, s. 16; wyd. z 2013 r., s. 32. 
jednocześnie wiedzą, że lepiej jest uchodzić za Polaków - jak głosi ankieta, przeprowadzona w powyższej wsi ${ }^{67}$.

Wśród licznych przykładów podał też wieś Ogrodniki, gminy lebiodzkiej, powiatu szczuczyńskiego, oficjalnie uchodzącą za polską:

Wszyscy uważają się za Polaków, lecz 50\% nie ma uświadomienia narodowego. [...] Jedni religię utożsamiają z narodowością, a inni przynależność państwową uważają za narodowość. Element światlejszy zdaje sobie sprawę, że nie są oni Polakami, lecz uchodzą za Polaków, bo narodowość ta im bardziej pochlebia niż białoruska, a inni to czynią dla interesu, w obawie, by władze nie zrobiły jakiegoś na nich nacisku. Wszyscy w codziennym życiu posługują się językiem białoruskim. Inteligencji miejscowej nie $\mathrm{ma}^{68}$.

Negatywny stosunek do Polski wśród miejscowej ludności, mającej problem z określeniem własnej tożsamości narodowej, wynikał z brutalnego „obchodzenia się z ludnością żołnierzy polskich podczas wojny, żołnierzy, rekrutujących się przeważnie z ziem południowo-wschodnich” oraz „napływu elementu obcego przeważnie z Małopolski do miejscowej administracji i samorządu, elementu, który ludności nie rozumie i traktuje ją z góry" ${ }^{\prime \prime 9}$. Ludność miejscowa urzędników i nauczycieli przysyłanych z Polski etnograficznej nazywała „galileuszami”, co było synonimem chytrości, przebiegłości, karierowiczostwa, dumy i złego obchodzenia się z ludnością. Stosunek do elementu napływowego był najczęściej negatywny - był on nielubiany i traktowany jak zaborca.

Pogranicze polsko-białoruskie w okresie 1939-1944 doświadczyło exodusu ludności, zwłaszcza polskiej - w czasie okupacji sowieckiej (1939-1941) i żydowskiej - w czasie niemieckiej (1941-1944). Po drugiej wojnie światowej zmieniły się granice państwowe granica polsko-radziecka (obecnie: białoruska) przesunęła się znacznie na zachód. Przyczyniło się do repatriacji ludności do Polski z terytorium Białoruskiej Socjalistycznej Republiki Radzieckiej. Często wystarczyło zadeklarować polską narodowość, aby wyjechać do Polski. I tu znowu zastosowano kryterium wyznaniowe - ci, którzy byli katolikami, bez problemu otrzymywali zgodę na wyjazd. Tym niemniej na Białorusi pozostała znaczna liczba osób, uważających się za Polaków, zaś w Polsce - uważających się za Białorusinów. Znacznej części ludności po obu stronach granicy kategoria narodowościowa nadal pozostawała obojętną.

67 Maszynopis, s. 20; wyd. z 2013 r., s. 35.

68 Maszynopis, s. 21; wyd. z 2013 r., s. 36.

69 Maszynopis, s. 28; wyd. z 2013 r., s. 41. 
W 1999 r. zgodnie ze statystyką spisową w Republice Białoruś było 396 tysięcy Polaków, co stanowiło 3,9\% ogółu mieszkańców Białorusi ${ }^{70}$. Jak wskazują dane statystyczne z poszczególnych spisów ludności, procentowy udział Polaków na Białorusi stopniowo zmniejszał się -w 1959 r. wynosił 6,7\% (539 tys.), w 1969 r. - 4,3\% (382 tys.), w 1979 r. - 4,2\% (403 tys.), w 1989 r. $-4,1 \%$ (418 tys. $)^{71}$. Dane te są kwestionowane przez działaczy polskich i przez badaczy z Polski. Według szacunków liczby te podnosi się do 1-1,9 mln Polaków ${ }^{72}$.

Kwestia tożsamości Polaków na Białorusi ciągle budzie wiele kontrowersji ze względu na powszechnie przyjmowane kryteria przynależności narodowej. Dla wielu Polaków na Białorusi podstawowym wyznacznikiem tożsamości nadal pozostaje wyznanie rzymskokatolickie. Wskazuje to na silny wpływ Kościoła na kształtowanie polskiej tożsamości narodowej i kulturowej wiernych ${ }^{73}$. Andrzej Sadowski przynależność do polskiej grupy narodowej na pograniczu polsko-białoruskim określił nastepująco:

Polakiem na pograniczu białorusko-polskim jest ten, kto Polakiem się czuje, kto urodził się w polskiej rodzinie, jest wyznania rzymskokatolickiego, pozostaje w bliskim związku z historią i polską kulturą, posługuje się językiem polskim. Autoidentyfikacja polskiej przynależności narodowej oparta jest głównie na religii rzymskokatolickiej, na kulturze społeczności lokalnych oraz na zróżnicowanym poczuciu związków z Polską jako ojczyzną ideologiczną ${ }^{74}$.

Jeden z działaczy polskich na Białorusi, Eugeniusz Skrobocki, redaktor naczelny „Magazynu Polskiego" swoją polskość uzasadniał tym, że

[...] przynależność do danego narodu jest [...] aktem woli samej jednostki. Osobiście chcę być Polakiem i dlatego nim jestem. [...] Gdybym tej wyraźnej woli nie miał, mógłbym mieszkać w Polsce, mówić po polsku, a pomimo tego prawdziwym Polakiem wówczas bym nie był. Odwrotnie - mogę mieszkać poza granicami Polski, mogę nie władać językiem polskim a pomimo to czuję się Polakiem, bo szczerze chcę nim byc $c^{75}$.

70 Статистический ежегодник Республики Беларусь, Минск 2000, s. 67.

71 Tamże.

72 C. Żołędowski, Białorusini i Litwini w Polsce, Polacy na Białorusi i Litwie. Uwarunkowania wspótczesnych stosunków między większością i mniejszościami narodowymi, Warszawa 2003, s. 139.

73 I. Kabzińska, Wśród „kościelnych Polaków”, s. 21.

74 A. Sadowski, Pogranicze polsko-białoruskie. Tożsamość mieszkańców, Białystok 1995, s. 239.

75 E. Skrobocki, Jestem dumny ze swej polskości, „Magazyn Polski”, 1992, nr 1, s. 21. 
Iwona Kabzińska, która prowadziła badania terenowe na Białorusi, doszła do wniosku, że

[...] na pytanie „Kto jest Polakiem na Białorusi?” należałoby odpowiedzieć: Każdy kto się za takiego uważa. Polakiem jest ten, kto „pisze się Polak”, tj. podaje narodowość polską w dokumentach, i ten, kto ma świadomość polskich korzeni, wywodząc swe pochodzenie od polskich przodków („,po predkach”) niezależnie od stanu wiedzy o nich. [...] Najczęściej jednak podstawowa dla autoidentyfikacji Polaków świadomość posiadania polskich korzeni wyrażana jest słowami: „Dziadowie i pradziadowie byli Polakami, to i my jesteśmy". [...] Otwarte pozostaje pytanie, na jakich podstawach budowali z kolei swą tożsamość rodzice i pradziadowie ${ }^{76}$.

Uznając wyznanie jako wyznacznik tożsamości, odwoływała się do świadomości społecznej, wyrażanej przez badaną przez nią społeczność. Stwierdziła, że „wśród mieszkańców Białorusi (nie tylko Polaków) żywy jest jednak sposób myślenia, zgodnie z którym 'Polak' znaczy tyle, co katolik. Podobnie określenie 'Ruski' występuje zamiennie z terminem 'prawosławny'. Grupa religijna jest więc utożsamiana z grupą etniczną (narodową)" ${ }^{77}$. Uzasadniała to wypowiedziami, spotykanymi wśród respondentów na Białorusi: „U nas jest takie pojęcie, że jak katolik to Polak”; [...] „Jestem Polakiem, bo chodzę do kościoła" ${ }^{78}$. Traktowanie synonimiczne Polaków i katolików powoduje często przy zmianie wyznania automatyczną zmianę narodowości, co zwłaszcza $\mathrm{w}$ latach dziewięćdziesiątych XX w. przejawiało się przez przyjmowanie chrztu ${ }^{79}$. Stereotyp Polaka katolika ciągle jest tak silny, że w rzeczywistości społeczno-politycznej postrzega się Polaków na Białorusi poprzez przynależność wyznaniową do Kościoła katolickiego nie tylko w świadomości społecznej, ale także w kręgach władzy, zarówno w Polsce, jak i na Białorusi. Jeden z księży, posługujących w Białorusi po 1989 r., stwierdził: „Polacy byli kojarzeni z kościołem katolickim, między Polakiem i katolikiem stawiano znak równości”. Z taką opinią zg̉adzała się też „Wspólnota Polska”"

Elżbieta Smułkowa, białorutenistka i ambasador Polski w Republice Białoruś w latach 1991-1995, wskazała, że

76 I. Kabzińska, Wśród „kościelnych Polaków”, s. 35.

77 Tamże, s. 37.

78 Tamże.

79 Tamże, s. 38.

80 K. Wasilewski, Opieka nad Polonią i emigracją po 1989 roku, „Przegląd Polsko-Polonijny”, 2011, nr 1, s. 62-63. 
[...] na Białorusi określenia Polak, polski i pochodne funkcjonują w różnych znaczeniach, a co za tym idzie - uproszczeniem jest traktowanie wszystkich obywateli RB określanych tym mianem jako jednolitej polskiej grupy narodowej. Twierdzenie to oparte jest na wnikliwych etnosocjologicznych badaniach terenowych (własnych i grupowych) oraz wielostronnych (różnośrodowiskowych) obserwacjach, jakie miałam okazję poczynić podczas czteroletniej pracy dyplomatycznej na Białorusi ${ }^{81}$.

Zwracała uwagę, że problem Polaków na Białorusi i w innych republikach byłego ZSRR powinien być badany „z uwzględnieniem rzeczywistości historycznej i współczesnej. Bez tego łatwo popełnić błąd przenoszenia kategorii pojęciowych badaczy na terminy i pojęcia, którymi posługują się badani; kategorie te często dość znacznie różnią się od siebie" ${ }^{\prime 2}$. Takimi pojęciami są określenia Polak i polski, które często stosuje się na Białorusi w opozycji do ruski i Białorusin w znaczeniu przynależności konfesyj-

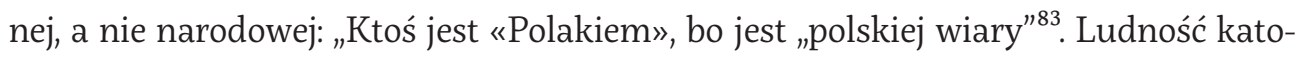
licka, która na Białorusi różni się od ludności prawosławnej wyznaniem i językiem modlitwy, na co dzień posługuje się tym samym dialektem białoruskim, językiem „prostym” i kultura polska jest jej „z reguły obojętna i raczej obca” ${ }^{\text {84 }}$. Wyjątek stanowi starsze pokolenie na Białorusi Zachodniej, które nauczyło się języka polskiego w polskiej szkole w okresie międzywojennym. Smułkowa wskazała także na kontekst natury socjalnej, przejawiający się w dawnym, ale trwałym podziale na szlachtę i chłopów (mużyków), w którym pierwszych uważa się często za Polaków, zaś drugich za Białorusinów; oraz na kontekst pochodzeniowy - potomków chłopów z centralnej Polski, którzy mieszkając w granicach Imperium Rosyjskiego, w czasie reformy Stołypina zakupili ziemię na Białorusi i osiedli tam na stałe ${ }^{85}$. Przemieszanie rodzin pod względem

81 E. Smułkowa, O wieloznaczności pojęcia 'Polak', 'polski' na Białorusi. (Z doświadczeń badacza i dyplomaty), w: taż, Białoruś i pogranicza. Studia o języku i społeczeństwie, Warszawa 2002, s. 552.

82 Tamże, s. 553.

83 Tamże; O tym, że wyznanie rzymskokatolickie na Białorusi, Ukrainie i w Rosji jest potocznie nazywane polską wiarą pisze też: Z. J. Winnicki, Uwagi o wpływie i skutkach stosowania niektórych metod i środków depolonizacyjnych na obszarze Ziem Białoruskich, na polska świadomość narodowa $w$ drugiej połowie Xx wieku i wspótcześnie, w: Problemy świadomości narodowej ludności polskiej na Białorusi, red. E. Skrobocki, Grodno 2003, s. 48.

84 E. Smułkowa, O wieloznaczności, s. 555.

85 Tamże, s. 555-556. 
narodowościowym na Białorusi jest zjawiskiem normalnym, wynikającym z bliskiego sąsiedztwa konfesyjnego oraz z historii tych ziem, znajdujących się w różnych systemach państwowych w ciągu xx w. Pojęcie „Polaka” na Białorusi jest wieloznaczne i nie zawsze określa etnonim, dlatego niebezpiecznym jest nakładanie ogólnopolskiej siatki pojęć na zrozumienie sytuacji ludnościowej na Białorusi ${ }^{86}$.

Oddziaływanie stereotypu Polaka katolika na pograniczu polsko-białoruskim jest tak silne, że kształtuje polską tożsamość narodową katolików zamieszkałych w Republice Białoruś, która opiera się na kryterium wyznaniowym bez głębszego przekonania na tle narodowym ${ }^{87}$. Kościół katolicki odgrywał decydującą rolę w zachowaniu i kształtowaniu polskiej tożsamości narodowej przez używanie języka polskiego w czasie nabożeństw i nadal ma „kluczowe znaczenie w przetrwaniu świadomości polskiej świadomości narodowej" ${ }^{\prime 8}$.

Polacy na Białorusi charakteryzują się niskim stopniem znajomości języka polskiego i posługiwania się nim w kontaktach międzyludzkich, a nawet w środowisku rodzinnym i domowym. Kwestia języka jest często wtórna wobec deklaracji narodowościowej, która stanowi często pretekst do nauki polskiego ${ }^{89}$. Wielu Polaków wykazuje także obojętność wobec języka polskiego i możliwości jego nauki, co powoduje dystansowanie się także wobec polskiego dziedzictwa kulturowego, m.in. literatury ${ }^{90}$. Komunikacja językowa wśród Polaków na Białorusi często odbywa się w języku białoruskim, rosyjskim lub tzw. trasianką.

Nauka języka polskiego często nie wynika z powodów kulturowych i przywiązania, lecz typowo koniukturalnych, związanych z możliwością wyjazdu na studia do Polski przez młode pokolenie i utylitarnych - znajomość języka ułatwia pobyt w Polsce. Iwona Kabzińska zacytowała jedną wypowiedź na ten temat: „Wiele osób robi to dla kariery lub by wysłać dzieci na wakacje do Polski”"1. Jak wynika z badań przeprowadzonych przez Romana Dzwonkowskiego, Olega Gorbaniuka i Julię Gorbaniuk, motywacją do nauki języka polskiego dla prawie połowy badanych przez nich katolików

86 Tamże, s. 558.

87 R. Dzwonkowski, O. Gorbaniuk, J. Gorbaniuk, Postawy katolików obrządku łacińskiego na Białorusi wobec języka polskiego, Lublin 2004, s. 157.

88 Tamże, s. 161; I. Kabzińska, Wśród „kościelnych Polaków”, s. 74-75.

89 I. Kabzińska, Wśród „kościelnych Polaków”, s. 52.

90 Tamże, s. 53.

91 Tamże, s. 60. 
była potrzeba używania go w życiu religijnym (46\%), 25\% - uzasadniało to motywami narodowymi i zaledwie 4\% - traktowało naukę języka polskiego jako element tradycji rodzinnej ${ }^{92}$. Nauka i znajomość języka polskiego stały się środkiem zyskania pewnego rodzaju korzyści, w tym również materialnych, np. stypendiów fundowanych podczas studiów w Polsce ${ }^{93}$. Jednostki i grupy uczące się języka polskiego trudno utożsamiać z ich polską świadomością narodową. Bardziej w tym względzie adekwatnym jest używanie języka polskiego w domu i kontaktach rodzinnych oraz przekazywanie go z pokolenia na pokolenie. Z przeprowadzonych badań wynikło, że udział języka polskiego w komunikacji z bliższym i dalszym otoczeniem systematycznie się zmniejsza - 21\% w środowisku dziadków do 4\% między dziećmi badanych ${ }^{94}$. Mimo wystarczającej kompetencji językowej (po nauce języka polskiego w szkole, na kursach lub w Polsce) w rodzinach nie rozmawia się po polsku. Wzrost liczby młodzieży mówiącej po polsku nie przekłada się na wzrost liczby rodzin komunikujących się między sobą w tym języku ${ }^{95}$. Często się zdarza, że nawet absolwenci uczelni w Polsce, wracający do rodzinnego domu, nie rozmawiają z rodzicami po polsku, tylko w tym języku, kóry wyniosły z domu - białoruskim („prostym”) lub rosyjskim ${ }^{96}$. Język polski zyskał miano języka sakralnego, w którym należy modlić się do Boga ${ }^{97}$. „Polacy-katolicy” tylko z pozoru są dwujęzyczni, gdyż ich językiem codziennym jest jedna z gwar białoruskich $^{98}$. W potocznym odbiorze społecznym potrzebę liturgii w Kościele w języku polskim uzasadnia się „polską wiarą", co potwierdzają wypowiedzi w czasie badań terenowych, np.: „Powinno być po polsku, bo u nas polska religia”, „Jak ja, katolik, mogę modlić się po białorusku?"99.

92 R. Dzwonkowski, O. Gorbaniuk, J. Gorbaniuk, Postawy katolików obrządku łacińskiego, s. 44.

93 Tamże, s. 116.

94 Tamże, s. 30, 38.

95 Tamże, s. 31; I. Kabzinska, Wśród „kościelnych Polaków”, s. 64.

96 R. Dzwonkowski, O. Gorbaniuk, J. Gorbaniuk, Postawy katolików obrządku łacińskiego, s. 31.

97 Tamże, s. 34, 75; E. Smułkowa, Rozwój Kościoła katolickiego w Republice Białoruś - problemy społeczno-polityczne i językowe, w: taż, Białoruś i pogranicza, s. 503-504; A. Engelking, Nacje, to znaczy grupy religijne. Wynikach etnograficznych badań terenowych na Grodzieńszczyźnie, „Kultura i Społeczeństwo”, 32 (1996) nr 1, s. 109-139; A. Engelking, „Boh adzin, wier mnoha”. Z badań etnograficznych na Grodzieńszczyźnie, „Konteksty”, 1996, nr 3-4.

98 E. Smułkowa, O wieloznaczności, s. 560.

99 R. Dzwonkowski, O. Gorbaniuk, J. Gorbaniuk, Postawy katolików obrządku łacińskiego, s. 87, 99. 
Iwona Kabzińska stwierdzała na podstawie badań terenowych, że trudno mówić np. o kresowej specyfice wielu zespołów folklorystycznych: „W ich repertuarze [...] przeważają utwory należące do kultury narodowej, często pochodzące z różnych regionów Polski. Bardzo mało jest natomiast miejscowej twórczości"100 . Wśród obrzędów ludowych, przedstawiano zaś białoruskie zwyczaje bożonarodzeniowe i pieśni dożynkowe ${ }^{101}$. Jak wynika z powyższych rozważań, tożsamość ludności na pograniczu polsko-białoruskim jest uzależniona od wielu czynników o charakterze obiektywnym i subiektywnym. Identyfikacja narodowa jest często wtórna wobec tożsamości kulturowej lub wyznaniowej. Występujący najczęściej indyferentyzm narodowościowy (tzw. tutejszość) przyczynia się do powstawania stereotypów czy sprowadzania kategorii tożsamości narodowej do tożsamości wyznaniowej („Polak-katolik”, „Białorusin-prawosławny"). Samo pogranicze polsko-białoruskie obszarowo bywa niedookreślone w związku z brakiem wyraźnych granic. Tak złożona sytuacja jest wynikiem różnych wpływów kulturowych, historycznych oraz politycznych. Szczególne znaczenie ma stosunkowo późne - w porównaniu ze świadomością polską czy rosyjską - kształtowanie się białoruskiej świadomości narodowej oraz brak tradycji państwa białoruskiego. Brak wyraźnych naturalnych granic etnicznych oraz tradycji narodowych białoruskich sprawia, że na pograniczu polsko-białoruskim granice tożsamości narodowej przebiegają przez rodziny - w jednej rodzinie mogą ujawniać się różne opcje narodowościowe: polska, białoruska, litewska, żydowska, rosyjska. Na dylematy tożsamościowe wpływają takie czynniki, jak: stan świadomości narodowej, język, przywiązanie do tradycji, znajomość historii, przynależność wyznaniowa, doświadczenia historyczne, sytuacja polityczna oraz koniunkturalizm.

Streszczenie: Tożsamośćl ludności na pograniczu polsko-białoruskim jest uzależniona od wielu czynników o charakterze obiektywnym i subiektywnym. Identyfikacja narodowa jest często wtórna wobec tożsamości kulturowej lub wyznaniowej. Występujący najczęściej indyferentyzm narodowościowy (tzw. tutejszość) przyczynia się do powstawania stereotypów czy sprowadzania kategorii tożsamości narodowej do tożsamości wyznaniowej („Polak-katolik”, „Białorusin-prawosławny"). Samo pogranicze polsko-białoruskie obszarowo bywa niedookreślone w związku z brakiem wyraźnych granic. Tak złożona sytuacja jest wynikiem różnych wpływów kulturowych, historycznych oraz politycznych. Szczególne znaczenie ma stosunkowo późne - w porównaniu ze świadomością polską czy rosyjską - kształtowanie się białoruskiej świadomości naro-

100 I. Kabzinska, Wśród „kościelnych Polaków”, s. 61-62.

101 Tamże, s. 62. 
dowej oraz brak tradycji państwa białoruskiego. Brak wyraźnych naturalnych granic etnicznych oraz tradycji narodowych białoruskich sprawia, że na pograniczu polsko-białoruskim granice tożsamości narodowej przebiegają przez rodziny - w jednej rodzinie mogą ujawniać się różne opcje narodowościowe: polska, białoruska, litewska, żydowska, rosyjska. Na dylematy tożsamościowe wpływają takie czynniki, jak: stan świadomości narodowej, język, przywiązanie do tradycji, znajomość historii, przynależność wyznaniowa, doświadczenia historyczne, sytuacja polityczna oraz koniunkturalizm.

\section{Bibliografia}

Al. S., Po spisie, „Przegląd Wileński”, 1932, nr 1-2.

Bohdanowicz A., O języku białoruskim, „Kuryer Litewski”, nr 14, 17 (30) września 1905.

[Bohuszewicz F.], Dudka białaruskaja Macieja Buraczka, Kraków 1891.

Chodubski A., O tożsamości na pograniczu kultur, w: Dziedzictwo przeszłości związków językowych, literackich i kulturowych polsko-wschodniosłowiańskich, t. 4: Kultura i literatura, red. J. F. Nosowicz, Białystok 2000.

Chodubski A., Swoistość kształtowania się tożsamości na pograniczach kultur, w: Europejskie dylematy i wyzwania: praca zbiorowa, red. S. Wojciechowski, Poznań 2004, s. 7-16.

Czeczott W. X., Około kwestji białoruskiej, „Litwa i Ruś, 6 (1913).

Dzwonkowski R., O. Gorbaniuk, J. Gorbaniuk, Postawy katolików obrządku łacińskiego na Białorusi wobec języka polskiego, Lublin 2004.

Eberhardt P., Przemiany narodowościowe na Białorusi, Warszawa [1994].

Engelking A., „Boh adzin, wier mnoha”. Z badań etnograficznych na Grodzieńszczyźnie, „Konteksty", 1996, nr 3-4.

Engelking A., Nacje, to znaczy grupy religijne. O wynikach etnograficznych badań terenowych na Grodzieńszczyźnie, „Kultura i Społeczeństwo”, 32 (1996) nr 1.

Huntington S., Zderzenie cywilizacji i nowy kształt ładu światowego, przeł. H. Jankowska, Warszawa 1997.

Jazepka S. z Z., Miasteczka Kiemieliszki, „Biełarus”, nr 27, 3 lipca 1914.

Kabzińska I., Wśród „kościelnych Polaków”. Wyznaczniki tożsamości etnicznej (narodowej) Polaków na Białorusi, Warszawa 1999.

Krysiński A., Liczba i rozmieszczenie Białorusinów w Polsce, „Sprawy Narodowościowe”, 2 (1928) nr 3-4.

Mackiewicz J., Pod każdym niebem, Londyn 1964.

Moroz M., „Krynica”. Ideologia u przywódcy białoruskiego katolicyzmu, Białystok 2001.

Narcyz-Ogończyk, Stosunki etnograficzne na Litwie, „Goniec Codzienny”, nr 35, 21 kwietnia (4 maja) 1910.

Pawlikowski M. K., Mińszczyzna, „Pamiętnik Wileński”, 1971.

Redakcja, W kwestii języka białoruskiego, „Kuryer Litewski”, nr 15, 18 września (1 października) 1905. 
Sadowski A., Pogranicze polsko-białoruskie. Tożsamość mieszkańców, Białystok 1995.

Skrobocki E., Jestem dumny ze swej polskości, „Magazyn Polski”, 1992, nr 1.

Smułkowa E., Białoruś i pogranicza. Studia o języku i społeczeństwie, Warszawa 2002.

Smułkowa E., O wieloznaczności pojęcia 'Polak', 'polski' na Białorusi. (Z doświadczeń badacza i dyplomaty), w: taż, Białoruś i pogranicza. Studia o języku i społeczeństwie, Warszawa 2002.

Smułkowa E., Wokół pojęcia pogranicza. Wschodnie i zachodnie pogranicze Białorusi, w: Pogranicza Białorusi $w$ perspektywie interdyscyplinarnej, red. E. Smułkowa, A. Engelking, Warszawa 2007.

Stankievič A., Biełaruski chryścijanski ruch, Vilnia 1939.

Straczuk J., Cmentarz i stót. Pogranicze prawosławno-katolickie w Polsce i na Białorusi, Wrocław 2006.

Tarasiuk D., Polacy białoruscy wobec idei wspótpracy narodów w latach 1905-1918, w: Europa unii i federacji. Idea jedności narodów i państw od średniowiecza do czasów współczesnych, red. K. Ślusarek, Kraków 2004.

Turonek J., Wacław Iwanowski i odrodzenie Białorusi, Warszawa 1992.

Wasilewski K., Opieka nad Polonią i emigracją po 1989 roku, „Przegląd Polsko-Polonijny”, 2011, nr 1.

Wasilewski L., Litwa i Białoruś. Przeszłość - teraźniejszość - tendencje rozwojowe, Kraków [1912].

Winnicki Z. J., Uwagi o wpływie i skutkach stosowania niektórych metod i środków depolonizacyjnych na obszarze Ziem Białoruskich, na polska świadomość narodowa $w$ drugiej połowie XX wieku i współcześnie, w: Problemy świadomości narodowej ludności polskiej na Białorusi, red. E. Skrobocki, Grodno 2003.

Wysłouch S., Stosunki narodowościowe na terenie województw wschodnich, Warszawa 2013. Zienkiewicz T., Polskie życie literackie w Mińsku w XIX i na początku XX wieku (do roku 1921), Olsztyn 1997.

Zubowicz P., Białoruś i Białorusini, „Praca”, 1910, nr 1.

Żołędowski C., Białorusini i Litwini w Polsce, Polacy na Białorusi i Litwie. Uwarunkowania współczesnych stosunków między większością i mniejszościami narodowymi, Warszawa 2003.

Żukowski W., Polacy i Białorusini, Wilno 1907.

Анісько Д., Дамінік Анісько - аўтабіяграфбія, „Божым Шляхам”, 1972, nr 1.

Арабей Л., Стану песняй..., Мінск 1990.

3 Беларусі і Літвы, „Наша Ніва”, nr 6, 4 (17) lutego 1910.

Луцкевіч А., Да гісторы Беларускага руху, Мінск 2003.

Статистический ежегодник Республики Беларусь, Минск 2000.

Ўласаў А., Вильня 25 апрыля, „Наша Нива”, nr 9, 25 kwietnia 1908.

Цётка, Выбраныя творы, Мінск 2001. 